\title{
Remaja Pengkonsumsi Pil Koplo di Desa Batu Ampar Kecamatan Kemuning Kabupaten Indragiri Hilir
}

\author{
Denis Septiana ${ }^{1}$, Nora Susilawati ${ }^{2}$, Erianjoni Erianjoni ${ }^{3}$ \\ 1,2,3 Universitas Negeri Padang \\ email: denisseptiana62@gmail.com
}

\begin{abstract}
Abstrak
Pil koplo (Nitrazepam) merupakan salah satu jenis narkoba jenis psikotropika. Pil koplo digunakan dikalangan medis untuk mengobati anjing gila. Namun, obat-obatan ini disalahgunakan oleh masyarakat terutama dikalangan remaja dengan cara dikonsumsi. Artikel ini bertujuan untuk mengungkap terkait faktor pendorong mengapa remaja Desa mengkonsumsi pil koplo. Penelitian ini dilakukan di Desa Batu Ampar, Kecamatan kemenuning, Kabupaten Indragiri hilir. Penelitian ini dianalisis dengan teori anomi dari Robert K.Merton,dan menggunakan pendekatan penelitian kualitatif dengan tipe penelitian studikasus. Hasil penelitian menunjukkan tujuan tersebut terdiri dari (1) pengaruh lingkungan pertemanan: a.) hobi nongkrong, b.) ketersediaan sarana dan prasarana (2) keluarga: a). anak bisa mencari uang sendiri, b.) sudah kecanduan. Dari hasil penelitian dapat disimpulkan bahwa remaja pengkonsumsi pil koplo banyak terdapat di Desa Batu Ampar dan sulit untuk dihilangkan kebiasaan mengkonsumsi obat-obatan tersebut.
\end{abstract}

Kata Kunci: Remaja, Mengkonsumsi, Pil Koplo.

\begin{abstract}
Koplo pill (Nitrazepam) is one type of psychotropic drug. Coplo pills are used in medical circles to treat crazy dogs. However, these drugs are misused by the community, especially among teenagers by way of consumption. This article aims to uncover the related driving factors for solar energy consumption of pylkoplo. This research was conducted in Batu Ampar Village, kemenuning District, Indragiri Hilir Regency. This study was analyzed with the theory of Robert K. Merton's theory, and used a qualitative research approach with the type of study research. The results showed these objectives consisted of (1) the influence of friendship environment: $a$.) hobby hangout, $b$. availability of infrastructure and infrastructure (2) family: a.) children are spending their own money, b.) already addicted. From the results of the research, it can be concluded that the understanding of consuming pylkoplobi can be found in the Village of Fish and it is difficult to eliminate the habit of consuming these drugs.
\end{abstract}

Keywords: Teenagers, Consuming, Koplo Pill 


\section{Pendahuluan}

Narkoba merupakan salah satu obat berbahaya yang dapat menyebabkan ketergantungan (adiksi) fisik dan psikologi terhadap para penggunanya. ${ }^{1}$ Narkoba juga merupakan jenis obat-obatan yang biasanya dipakai oleh para dokter untuk membius para pasien saat melakukan operasi atau obat-obatan yang digunakan untuk proses penyembuhan penyakit tertentu. Akan tetapi, pada saat sekarang ini beberapa kalangan masyarakat menggunakan obat-obatan terlarang tersebut dengan tujuan yang tidak baik, sehingga menimbulkan efek bahwa obat-obatan yang digunakan untuk medis tersebut menjadi obatobatan yang terlarang.

Di Indonesia, narkoba sendiri memiliki nama lain yakni Napza (narkotika, psikotropika, danzatadiktif). Narkoba sendiri banyak jenisnya, salah satunya adalah pil koplo. Pil koplo (nitrazepam) merupakan salah satu narkoba jenis psikotropika yang di kalangan medis digunakan untuk mengobati anjing gila. Tetapi karena efek obat-obatan tersebut dianggap dapat memberikan ketenangan bagi penggunanya, maka banyak pihak-pihak tertentu berupaya mendapatkan obat-obatan tersebut untuk dikonsumsi, sehingga pada tingkat stadium berikutnya para pengguna menjadi ketagihan atau ketergantungan (syndroma). ${ }^{2}$

Akhir-akhir ini perdagangan pil koplo semakin meluas. Sasarannya bahkan menembus keberbagai lapisan masyarakat. Peredarannyapun sampai ke kampung-kampung. Salah satu daerah yang dilanda penyalahgunaan pilkoplo yaitu di Desa Batu Ampar. Konsumennya adalah masyarakat umum, akan tetapi lebih banyak disalahgunakan oleh kalangan remaja yang masih berusia 13-21 tahun.

Narkoba jenis psikotropika yang digunakan oleh kalangan remaja di Desa Batu Ampar ini adalah pilkoplo jenis Dextro, Tramadol, serta Aditusin yang dijual bebas. Desa Batu Ampar berada di Kecamatan Kemuning, Kabupaten Indragiri Hilir. Kecamatan Kemuning sendiri memiliki 12 desa termasuk di dalamnya Desa Batu Ampar. Jika dibandingkan dengan desa-desa lain yang ada di Kecamatan Kemuning Desa Batu Ampar para remajanya adalah pengguna aktif pil koplo. ${ }^{3}$ Hal tersebut dapat di lihat dari data yang di dapatkan oleh peneliti dari data Rumah Sakit dan Kantor Polisi, dari perbandingan masing-masing desa tersebut dapat disimpulkan bahwa para remaja Desa Batu Ampar lebih mendominasi jika dibandingkan dengan beberapa desa lainnya

Pada topik ini, peneliti lebih fokus kepada faktor-faktor penyebab remaja mengkonsumsi pil koplo di Desa Batu Ampar Kecamatan Kemuning Kabupaten Indragiri Hilir. Di Desa Batu Ampar tersebut terdapat banyak remajanya yang menjadi penyalahguna obat-obatan seperti pilkoplo. Dimana peneliti menemukan dalam masyarakat terdapat banyak dari para remajanya yang mengkonsumsi pil koplo jika dibandingkan dengan desa-desa lain di sekitarnya. Tujuan dalam penelitian ini adalah untuk mengungkap faktor penyebab mengapa remaja Desa Batu Ampar lebih banyak mengkonsumsi pil koplo dibandingkan desa lainnya.

Permasalahan di atas, dianalisis dengan teori anomi dari Robert K. Merton. Melalui teori ini Merton melihat anomi tidak akan muncul sejauh masyarakat mampu menyediakan sarana kelembagaan untuk mencapai tujuan-tujuan kultural tersebut. Struktur yang bertanggung jawab atas perilaku orang. Merton juga menempatkan ketidakseimbangan struktur dalam masyarakat sebagai penyebab penyimpangan, di mana tujuan-tujuan budaya lebih ditekankan dari pada cara-cara yang tersedia untuk mencapai tujuan-tujuan budaya itu.

\footnotetext{
${ }^{1}$ Sari, Intan Kumala dan Iwan Andhyantoro. 2012. Kesehatan Reproduksi. Jakarta: Salemba Medika. Hal 129 ${ }^{2}$ Elly, M. Setiadi, Usman Kolip. 2011. Pengantar Sosiologi. Jakarta: Kencana. Hal 204

${ }^{3}$ Wawancara dengan Kapolsek AKBP Ari Surya Wardana.Polsek kemuning. Pada Tanggal 30 Oktober 2017
} 


\section{Metode Penelitian}

Penelitian ini dilakukan yakni di Desa Batu Ampar, Kecamatan Kemuning, Kabupaten Indragiri Hilir, dengan memakai pendekatan penelitian kualitatif dan tipe penelitian studi kasus. Untuk pemilihan informan penelitian dilakukan secara purposive sampling dengan jumlah informan sebanyak 30 orang. Data penelitian diperoleh melalui kegiatan observasi, wawancara dan studi dokumen. ${ }^{4}$ Agar data yang diperoleh bisa dipercaya (absah), maka dalam penelitian ini dilakukan proses triangulasi data.

Triangulasi data dilakukan melaui cara diberikan pertanyaan yang sama kepada informan yang berbeda. Jawaban yang relatif sama pada masing-masing informan dianggap valid apabila sesuai dengan pengamatan dan studi dokumen yang peneliti peroleh maupun dengan menggunakan teknik lainnya.

Kemudian data yang diperoleh dianalisis dengan menggunakan teknik analisis data yang dikemukakan oleh Milles dan Huberman dengan langkah reduksi data, display data, dan tahap menarik kesimpulan/verifikasi. ${ }^{5}$ Aktivitas dalam analisis data ini, dilakukan secara terus menerus pada setiap tahap penelitian hingga tahap penelitian ini selesai.

\section{Remaja Pengkonsumsi Pil Koplo}

Berbagai macam penyalahgunaan narkoba yang dilakukan dalam masyarakat, salah satunya yaitu pil koplo (nitrazepam) yang dikenal dikalangan medis sebagai salah satu obat untuk mengobati anjing gila. Narkoba jenis ini ada berbagai macam bentuk dan merk diantaranya Dextro, Tramadol, dan Aditusin. Pil koplo (nitrazepam) yang seharusnya hanya boleh digunakan melalui resep medis, akan tetapi disalahgunakan dalam masyarakat Desa Batu Ampar terutama oleh kalangan remaja dengan cara dikonsumsi secara sembarangan.

Seiring dengan perkembangan zaman yang terus mengalami perubahan baik dalam bidang teknologi, informasi dan tranportasi menyebabkan proses penyebaran narkoba jenis pil koplo ini sangat mudah dan mempengaruhi dalam proses penyebarannya, sehingga untuk mendapatkannya sangatlah mudah oleh masyarakat terutama oleh para kaum remaja. Para remajapengkonsumsi pil koplo ini bahkan menjadi seorang pecandu

Polemik penyalahgunaan pil koplo di dalam masyarakat Desa Batu Ampar ini sudah lama terjadi, bahkan sudah ada dari awal berdirinya desa itu sendiri, hanya saja terjadi perubahan pada bentuk dan nama. Para penyalahguna pil koplo ini sendiri tidak hanya dikalangan para orang-orang dewasa saja melainkan juga di kalangan para remaja. Penanganan penyalahgunaan pil koplo dalam masyarakat seharusnya menjadi tanggung jawab semua pihak dan harus melibatkan semua aspek terkait yang harus ikut andil agar proses pengendalian terhadap penyimpangan ini dapat tercapai. Namun, saat sekarang keterlibatan para lembaga pengendalian sosial tidak mampu untuk mengontrol penyalahgunaan obat-obatan tersebut, sehingga penyalahguna obat-obatan tersebut masih leluasa menggunakannya.

Hasil temuan menunjukkan bahwa terdapat beberapa faktor pendorong mengapa remaja di Desa Batu Ampar lebih banyak mengkonsumsi pil koplo dibandingkan dengan desa lain. Struktur yang ada dalam masyarakat memiliki peran yang penting dalam pembentukan kepribadian setiap individu sehingga menciptakan suatu pola hubungan yang saling terkait. Adapun faktor pendorong mengapa remaja di Desa Batu Ampar banyak mengkonsumsi pil koplo, diantaranya yang peneliti ditemukan yaitu:

\footnotetext{
${ }^{4}$ Basrowi \& Suwandi. 2008. Memahami Penelitian Kualitatif. Jakarta: Rineka Cipta. Hlm. 94

${ }^{5}$ Afrizal. 2016. Metode Penelitian Kualitatif. Sebuah Upaya Mendukung Menggunakan Penelitian Kualitatif

dalam Berbagai Disiplin Ilmu. Jakarta: PT. Raja Grafindo Persada. Hlm. 180
} 


\section{Pengaruh pergaulan pertemanan}

Faktor pendorong remaja pengkonsumsi pil koplo disebabkan karena adanya interaksi dengan lingkungan sekitarnya terutama dengan lingkungan pergaulannya. Lingkungan akan membentuk kepribadian seseorang, jika lingkungan disekitarnya baik maka akan berdampak positif, akan tetapi jika sebaliknya lingkungannya disekitarnya buruk maka akan berdampak negatif. Adapun yang menjadi faktor dari pengaruh pergaulan pertemanan terhadap penyalahgunaan pil koplo yang peneliti temukan diantaranya disebabkan oleh:

\section{a. Hobi nongkrong}

Hobi merupakan suatu kegiatan yang dilakukan seseorang di waktu luang. Hobi yang dimiliki seseorang beraneka ragam, yang mana hobi ini di lakukan untuk mengisi waktu luang. Biasanya seseorang memiliki hobi yang positif. Akan tetapi lain halnya dengan remaja yang ada di Desa Batu Ampar, kebanyakan dari remaja di desa tersebut mereka suka melakukan kegiatan nongkrong-nongkrong bersama teman-teman sebayanya yang berdampak pada hal-hal yang negatif, seperti menggunakan lem, minum-minuman keras, dan menggunakan obat-obatan terlarang seperti pil koplo.

\section{b. Ketersediaan sarana dan prasarana}

Dalam kegiatan kehidupan sehari-hari ketika hendak melakukan sesuatu hal diperlukan adanya faktor penunjang, agar yang diinginkan tersebut dapat tercapai, maka salah satu penunjangnya yaitu faktor tersediaan sarana, yang mana faktor sarana yang peneliti temukan di lapangan diantaranya seperti alat-alat transportasi (mobil dan motor) serta prasarana (rumah, jalan raya, jembatan, kebun sawit) yang memadai. Akan tetapi, para pelaku penyalahguna pil koplo yang memanfaatkan sarana dan prasarana tersebut untuk halhal yang negatif.

\section{Keluarga}

Keluarga merupakan salah satu kelompok atau kumpulan manusia yang hidup bersama sebagai satu kesatuan atau unit masyarakat terkecil dan biasanya memiliki ikatan darah. Keluarga adalah lembaga pengendalian sosial yang paling banyak bertanggung jawab terhadap setiap perilaku yang dilakukan anak-anaknya. Setiap perilaku yang dimiliki seorang anak harus bisa di kontrol oleh setiap keluarnya masing-masing, disinilah peran orang tua sangat dibutuhkan. Adapun faktor yang menjadi kendala orang tua sebagai keluarga dari remaja penyalahguna pil koplo untuk meminalisir agar anak-anaknya tidak lagi mengkonsumsi pil koplo, faktor kendala yang peneliti temukan diantaranya:

a. Anak sudah mampu mencari uang sendiri

Pekerjaan adalah sesuatu yang dilakukan seseorang dengan tujuan untuk mendapatkan suatu hal, terutama untuk mendapatkan uang. Pekerjaan yang dilakukan seseorang ada banyak ragamnya. Umumnya suatu pekerjaan hanya dilakukan oleh orang-orang dewasa saja. Akan tetapi, pada saat sekarang ini, pekerjaan juga sudah banyak dilakukan oleh anak-anak remaja.

Alasan mereka melakukan pekerjaan tersebut juga beragam, ada yang hanya ingin membantu perekonomian orang tuanya, ada juga yang bertujuan untuk memenuhi kebutuhannya sendiri. akan tetapi tidak pula bisa dipungkiri hal ini juga berdampak ke hal-hal yang negatif, seperti halnya pada remaja Desa Batu Ampar. Para remaja tersebut banyak menggunakan uang hasil dari pekerjaan yang mereka lakukan untuk membeli hal-hal dilarang, seperti membeli minum-minuman keras dan obat-obatan seperi pil koplo.

b. Jadi seorang pecandu

Penggunaan obat-obatan seperti pil koplo seharusnya berdasarkan dari resep dokter, harus ada takaran tertentu dalam penggunaannya sesuai yang dianjurkan dalam dunia medis. Akan tetapi, apa yang dilakukan oleh remaja di Desa Batu Ampar, para remaja tersebut mengkonsumsi obat-obatan seperti pil koplo secara sembarangan dan berlebihan tanpa ada 
takaran yang dianjurkan oleh dokter. Penggunaan secara berlebihan tersebut menyebabkan mereka ketagihan untuk terus mengkonsumsi sehingga mereka menjadi seorang pecandu. Hal ini manjadi faktor kenapa para orang tua dari remaja pengkonsumsi pil koplo tersebut sulit untuk membuat anak-anak mereka untuk berhenti mengkonsumsi.

\section{Penutup}

Terdapat beberapa faktor pendorong mengapa remaja di Desa Batu Ampar lebih banyak mengkonsumsi pil koplo dibandingkan dengan desa lain. Struktur yang ada dalam masyarakat memiliki peran yang penting dalam pembentukan kepribadian setiap individu, sehingga menciptakan suatu pola hubungan yang saling terkait

\section{Daftar Pustaka}

Afrizal.(2016). Metode Penelitian Kualitatif. Sebuah Upaya Mendukung Menggunakan Penelitian Kualitatif dalam Berbagai Disiplin Ilmu. Jakarta: PT. Raja Grafindo Persada.

Basrowi \& Suwandi.(2008). Memahami Penelitian Kualitatif. Jakarta: Rineka Cipta.

Elly, M. Setiadi, Usman Kolip.(2011). Pengantar Sosiologi. Jakarta: Kencana.

Sari, Intan Kumala dan Iwan Andhyantoro.(2012). Kesehatan Reproduksi. Jakarta: Salemba Medika. 